Int. J. Morphol.,

33(2):446-451, 2015.

\title{
Effects of 14 Weeks Resistance Training on Muscle Tissue in Wistar Rats
}

\author{
Efecto de 14 Semanas de Entrenamiento de Resistencia en el Tejido Muscular de Ratas Wistar
}

\begin{abstract}
Robson Chacon Castoldi*******; Giovana Rampazzo Teixeira ${ }^{* *}$; Olga Cristina de Mello Malheiro**; Regina Celi Trindade Camargo*; William Dias Belangero***** \& José Carlos Silva Camargo Filho*
\end{abstract}

CASTOLDI, R. C.; TEIXEIRA, G. R.; MALHEIRO, O. C. M.; CAMARgO, R. C. T.; BELANGERO, W. D. \& CAMARGO

FILHO, J. C. S. Effects of 14 weeks resistance training on muscle tissue in Wistar rats. Int. J. Morphol., 33(2):446-451, 2015.

SUMMARY: The objective of the present study was to analyze the effects of 14 weeks of resistance training on muscle tissue in Wistar rats. 20 male Wistar rats were used in the study; 10 allocated to the untrained group (Group 1) and 10 to the trained (Group 2). The physical training (PT) program consisted of four sets of ten water jumps, three times a week for 14 weeks. A progressive increase in load was applied from the $14^{\text {nd }}$ to the $42^{\text {nd }}$ day. Following this, the animals were euthanized with an overdose of potassium chlorate (100 mg/ $\mathrm{kg}$ ) applied intraperitoneally. The ventral portion of the gastrocnemius muscle was removed for histological processing. The muscles were frozen in liquid nitrogen and cut into thicknesses of $5 \mu \mathrm{m}$ using a rotative microtome. The sections were stained with hematoxylineosin for general analysis of the structure of muscles and analysis of the area of muscle fibers. The reaction with NADH-TR was utilized for differentiation between fast twitch (FT) and slow twitch (ST) fibers. The sections subjected to staining and histochemical reactions were observed in normal and polarized light and photomicrographed using a microscope (Zeiss $\left.{ }^{\circledR}\right)$. The measurement of muscle fibers was performed using AxioVision software (Zeiss $\left.{ }^{\circledR}\right)$. Statistical analysis was performed using the Student t test for analysis of the samples average. An average area of $5061.29 \mu \mathrm{m}^{2}$ for Group 1 versus $5768.93 \mu \mathrm{m}^{2}$ for Group 2 was observed. It can be concluded that 14 weeks of training with water jumps was effective in increasing muscle area. An increase in transverse area section (TAS) of ST and FT was also verified in the trained group.

KEY WORDS: Swimming; Striated muscle; Physical Exercise.

\section{INTRODUCTION}

Physical training (PT) emerged in ancient Greece. At that time, warriors utilized PT for incrementing body force and physical form. Thus, they were better able to win in combat and expand their territory; which were aspirations during the epoch (Sigoli \& De Rosi, 2004). With the passing of centuries, cities were formed, followed by the industrial revolution and the utilization of the body as a means to win was replaced (Ferolla et al., 2010). Over time, PT became a means of achieving higher sports performance; and today, is also employed in the quest for health improvement and aesthetics (Lüdorf, 2009; Freitas Júnior et al., 2009; Castoldi et al., 2010; Kottke et al., 2009).

In higher sports performance force training has been shown to improve actin and myosin filaments. In addition, it contributes to the structural development of muscle cells, an increment in mitochondrial numbers, nuclei and in the circulation system (Taaffe et al., 2009; Meloni, 2005; Lanza \& Nair, 2010; Carmo et al., 2008; Cooper, 2001).

Swimming exercises have been widely explored in the literature as being easy to apply and possessing greater control of variables (Spagonol et al., 2012). However, in many cases training is limited to four or eight weeks of physical training, longer periods with ten or more weeks are rarely investigated.

In human studies the form of evaluation is to measure body circumference. This anthropometric technique can be efficient in evaluating muscle tone, but does not identify alterations in muscle fibers or fast twitch (FT) and slow twitch (ST).

\footnotetext{
* Physiotherapy Department. São Paulo State University "Júlio de Mesquita Filho" - UNESP, Presidente Prudente campus, São Paulo, Brazil.

** Physical Education Department. São Paulo State University "Júlio de Mesquita Filho" - UNESP, Presidente Prudente campus, São Paulo, Brazil.

*** Physical Education Department. São Paulo West University - UNOESTE, São Paulo, Brazil.

****** Medical Science Department. Campinas State University - UNICAMP, São Paulo, Brazil.
} 
Thus, the objective of the present study was to analyze the effects of 14 weeks of resistance training on the muscle tissue of Wistar rats.

\section{MATERIALS AND METHOD}

Sample. The study utilized 20 male Wistar rats obtained from the Anatomical Department of the IBB/UNESP at 21 days of age and maintained in polyethylene boxes $(40 \times 30$ $\mathrm{x} 15 \mathrm{~cm}$ ), with five animals to a box, luminosity (12 h light and $12 \mathrm{~h}$ dark cycle) and temperature $\left(20\right.$ to $\left.25^{\circ} \mathrm{C}\right)$ were controlled. The animals had free access to food and water (Nuvital®) ad libitum.

The experimental protocol followed the ethical principles of animal research adopted by the Brazilian College of Animal Research (Protocol 83/07-CEEA/IBB).

Experimental Groups. At 90 days of age (adult age), the animals were allocated to two experimental groups, one untrained group (Group $1 ; n=10$ ) and the other submitted to physical training (Group 2; $\mathrm{n}=10$ ). The physical training (PT) protocol was started for resistance training using aquatic jumps.

Physical resistance training protocol in the liquid medium The animals were submitted to jumping sessions in PVC cylinders, with water at $30{ }^{\circ} \mathrm{C}$ and a depth of $38 \mathrm{~cm}$. The weight overload was placed on the frontal trunk region of each animal using a waistcoat which had been specifically modulated for this experiment (Spagnol et al.; Castoldi et al., 2013).

The PT program was continued for 14 consecutive weeks. Sessions of aquatic jumps were performed 3 times per week, starting with an overload of 50\% body weight and ending with $70 \%$.

A gradually increasing adjustment period was established as follows: two sets of five jumps on the first day of PT; three and four sets of five jumps on the second and third days, respectively; four sets of seven jumps on the fourth day; four sets of nine jumps on the fifth day and four sets of 10 jumps from the $6^{\text {th }}$ to the $13^{\text {th }}$ day.

After this period an increment of $10 \%$ was added to the overload, corresponding to an intensity of $60 \%$ of each animal's body weight from the $14^{\text {th }}$ to $27^{\text {th }}$ day, with four sets of 10 jumps. Finally, from the 28th to the 42nd day the intensity was established at $70 \%$ of body weight until the end of the experiment. There was an established interval of
$60 \mathrm{~s}$ of passive recovery between every set.

Tissue Collection. At 190 days of age the animals were submitted to euthanasia. Samples of the ventral portion of the Gastrocnemius muscle were obtained, inserted in liquid nitrogen and stored in a freezer at $-80^{\circ} \mathrm{C}$.

Histological Process. Sections of $5 \mu \mathrm{m}$ were cut using a rotative microtome and slides of transverse sections were collected and colored with hematoxylin-eosin (HE). In addition the NADH-TR reaction was used for analyses of fast twitch (FT) (light fiber) and slow twitch (ST) (dark fibers).

Morphometric Study. The slides submitted to HE coloration and histochemical reactions were observed in normal and polarized light and photographed with a Carl ZEISS® microscope. The mean area of gastrocnemius muscle fibers was determined by interactive marking of the slides colored by HE and NADH-TR reaction; a minimum of 100 fibers and 10 slides from each animal AxioVision (ZEISS $\left.{ }^{\circledR}\right)$. The values were obtained in micrometers $(\mu \mathrm{m})$.

Statistical Analyses. The "Komoronov-Smirnov" test was used for identification of the normal distribution of data. The Student t test was used for the comparison between trained and untrained animal groups. All procedures adopted an error of $5 \%(\mathrm{p}<0.05)$. The statistical software SPSS ${ }^{\circledR}$ (version 17.0) was used for analyses.

\section{RESULTS}

After analyzing the data, it was observed that the Group 2 (trained) animals showed an increase in mean area in relation to group 1 (untrained); the muscle fibers of the trained group were $707 \mu \mathrm{m}^{2}$ larger than the untrained animals.

Compared to Group 1, the Group 2 rats demonstrated an increment of $696.17 \mu \mathrm{m}^{2}$ and $520.9 \mu \mathrm{m}^{2}$ in fast and slow twitch fibers respectively (Fig. 1).

Microscopic analysis showed structural components in muscle fibers in group 1 (Figs. 2 and 3). Microscopic analysis showed the hypertrophic process in muscle fibers in group 2 (Figs. 4 and 5).

Finally, group 2 demonstrated the hypertrophic process in type I fibers (slow twitch) and type II fibers (fast twitch). This fact demonstrated that exercise training produced alterations in both types of fibers (Figs. 6 and 7). 
CASTOLDI, R. C.; TEIXEIRA, G. R.; MALHEIRO, O. C. M.; CAMARGO, R. C. T.; BELANGERO, W. D. \& CAMARGO FILHO, J. C. S. Effects of 14 weeks resistance training on muscle tissue in Wistar rats. Int. J. Morphol., 33(2):446-451, 2015.

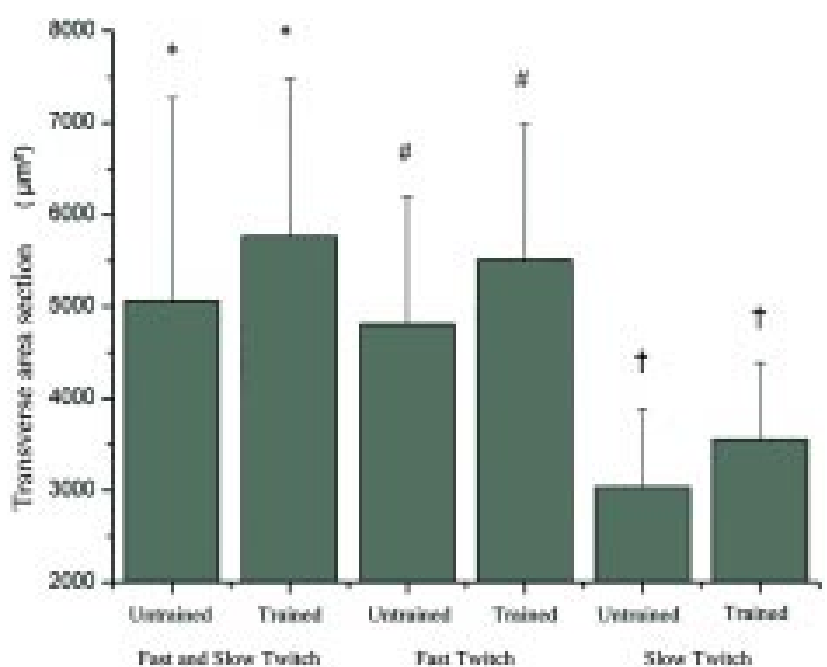

Fig. 1. Comparison of transverse area section of the medial gastrocnemius muscle in trained and untrained rats $(\mathrm{n}=20)$. TAS: Transverse area section $(*, \#, \dagger)$ : Statistical difference between trained and untrained rats. Groups comparisons: Student $t$ test with an error of $5 \%$ ( $p$ value $p<0.05)$.
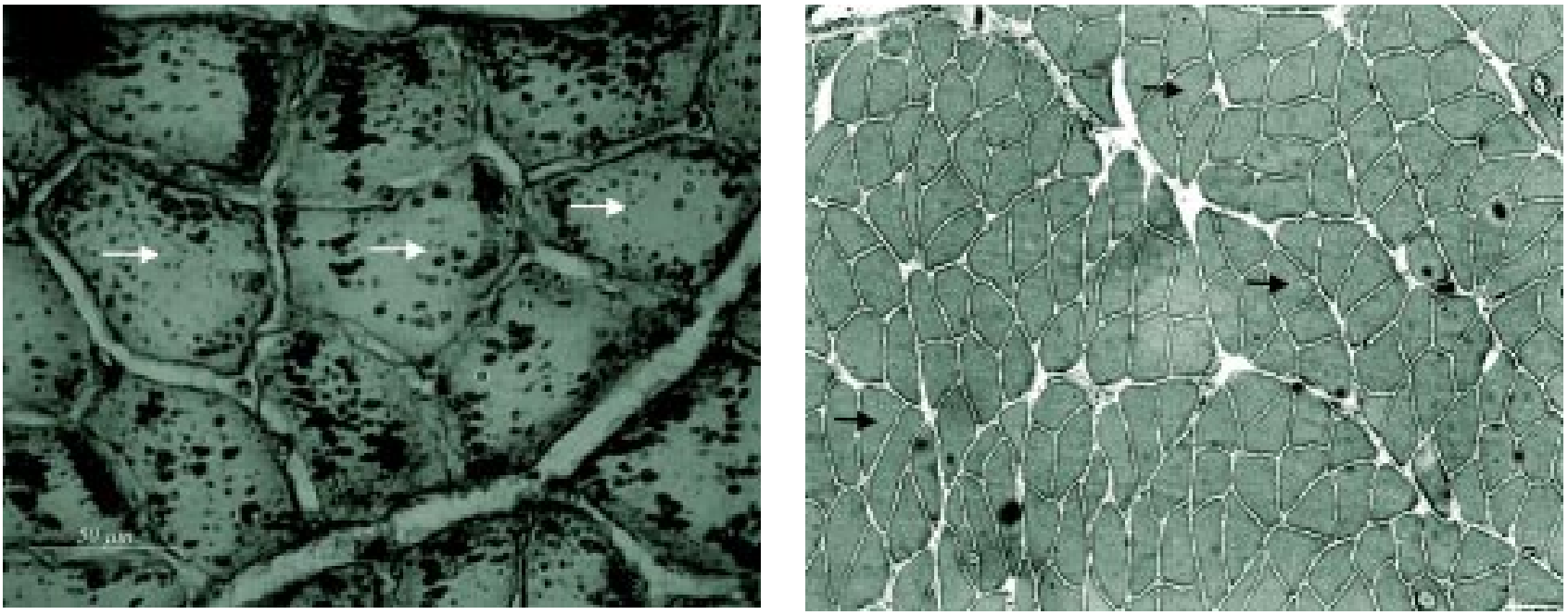

Fig. 2. Muscle fibers in the gastrocnemius muscle of untrained rats. Cross-section colored with hematoxylin and eosin. Magnified 40x. The arrows indicate muscle fibers.

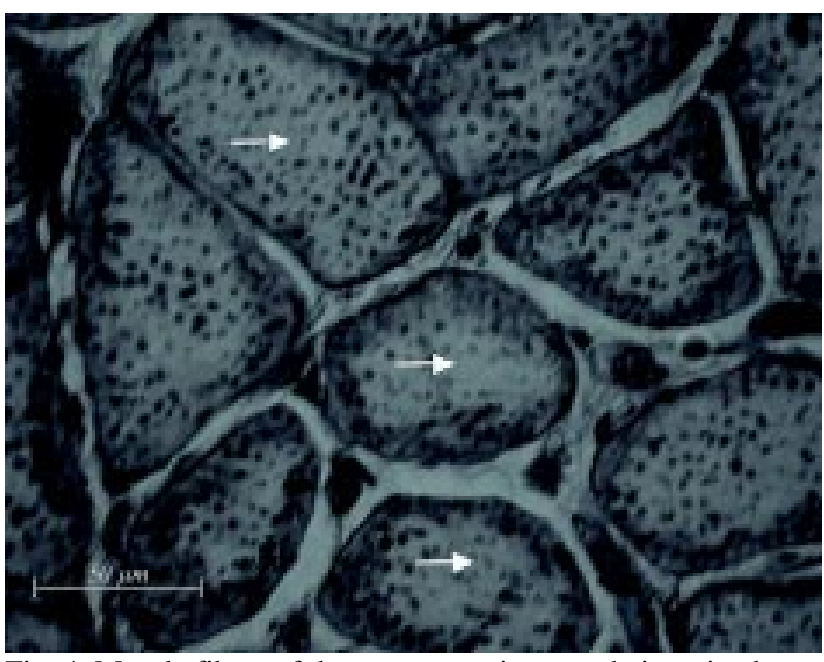

Fig. 4. Muscle fibers of the gastrocnemius muscle in trained rats. Cross-section colored with hematoxylin and eosin. Magnified 40x. The arrows indicate muscle fibers.
Fig. 3. Cross-sectional area of untrained animals. Cross-section colored with hematoxylin and eosin. Magnified 10x. The arrows indicate muscle fibers.

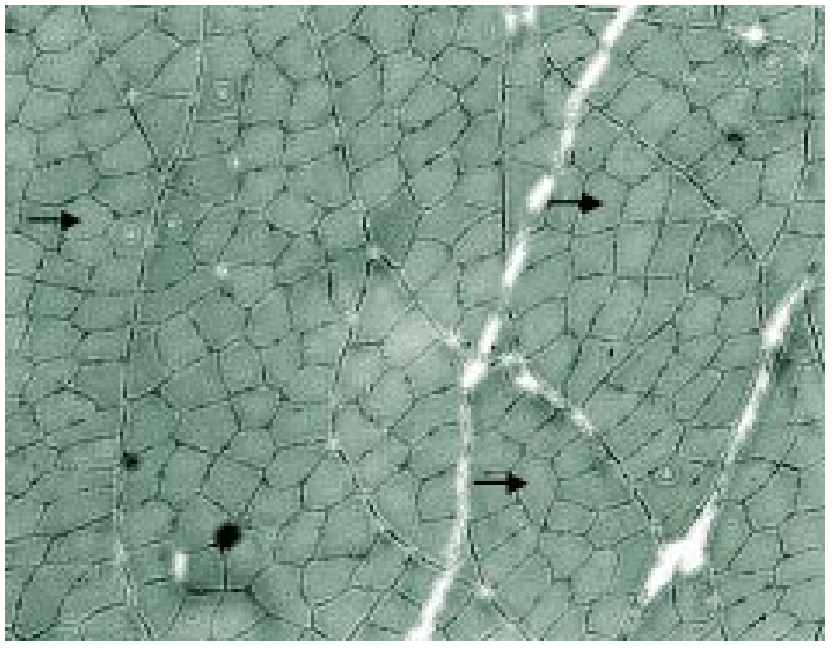

Fig. 5. Cross-sectional area in untrained animals. Cross-section colored with hematoxylin and eosin. Magnified 10x. The arrows indicate muscle fibers. 


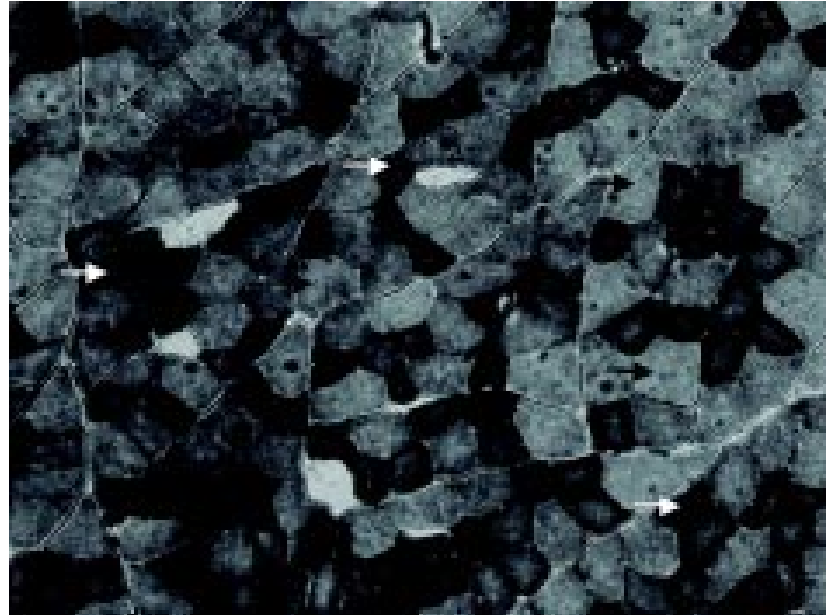

Fig. 6. Analysis of muscle fiber in untrained rats for NADH-TR reaction.Cross-section of muscle fibers for NADH-TR reaction. Magnified 10x. The black arrows indicate fast twitch muscle fibers. The white arrows indicate slow twitch muscle fibers.

\section{DISCUSSION}

The present study investigated muscle fibers in trained and untrained rats. The experiment consisted of 14 weeks of PT with aquatic jumps. An increase in TAS muscle fibers in the trained animals was verified, in addition to the hypertrophic process in slow twitch and fast twitch fibers.

The gastrocnemius muscle was chosen for the analyses as it is located in the lower region of the body and has the main functions of body support and locomotion (Zorzetto, 1979). Thus, the training methodology used in the present study produced alterations in the muscle analyzed (aquatic jumps).

It was observed that the mean area of muscle fibers increased considerably after 14 weeks of training. The increased area found in the trained group was $707 \mu \mathrm{m}^{2}$ greater than the untrained group; this increase is due to the muscle hypertrophic process.

This fact results from muscle adaptation provoked by the stress produced by physical training. Research has shown that the gastrocnemius muscle is very engaged in exercise training and this fact results in an increase in protein synthesis and induces diverse biochemical reactions (Carmo et al., 2011; Castoldi et al., 2013).

The hypertrophic process is characterized by an increase in volume of myosin and actin filaments present in muscle sarcolemmal, with muscle glycogen, water and ions of calcium. Other components such as satellite cells, growth

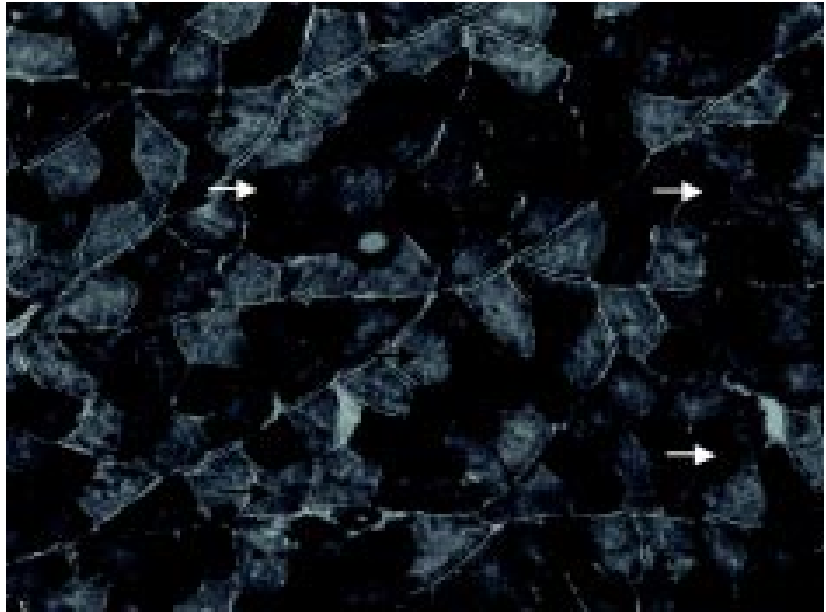

Fig. 7. Analysis of muscle fibers in untrained rats for NADH-TR reaction. Cross-section of muscle fibers for NADH-TR reaction. Magnified 10x. The black arrows indicate fast twitch muscle fibers. The white arrows indicate slow twitch muscle fibers.

hormone (GH), insulin and testosterone also influence this process (Pinto et al., 2004; Machado \& Ribeiro, 2004).

In addition to an increase in muscle area, an increase in performance was observed. At the beginning of the training period, the animals trained with a load of $50 \%$ of body weight and by the $14^{\text {th }}$ week, this had increased to $70 \%$ of body weight.

Studies have shown that an increase in force contraction is proportional to TAS (Teixeira et al., 2008). In one study, realized in humans, it was possible to verify that the force of the individual modified in accordance with muscle density, as well as the period of training or detraining (Taaffe et al.).

It is also known that the occurrence of increased force is a result of neurological adaptation and fiber innervation. The neural adaptation results from the recruitment of muscle fibers and the decrease in sympathetic inhibition (Fleck \& Kraemer, 2006).

According to reports in the literature, it is noted that nerve cells (neurons) are capable of adapting to the conditions imposed by exercise and thereby influence innervations and nerve endings (Deforges et al., 2009).

Moreover, an increase in cross-sectional area was observed in both slow twitch and fast twitch fibers. Despite the protocol utilized in the present study being characterized for "force training", it also increased the TAS of oxidative 
fibers and this fact demonstrates the contribution of slow twitch fibers to adaptations.

The process of increasing muscle fiber area in the gastrocnemius is facilitated according to the proportion of fast twitch fibers in its composition. According to Armstrong (1984), the percentage of glycolytic fibers varies between $94 \%$ and $95 \%$ respectively. Thus, this distribution contributes to the hypertrophic process.

In this way, the present study collaborates with the literature in identifying an increase in the mean area of muscle fibers in the gastrocnemius muscle in rats submitted to a protocol with training jumps. Furthermore, this increase was verified quantitatively. However, the present study was limited to analyzing muscle fiber area in rats submitted to 14 weeks of training with jumps. Future studies which explore the sarcoplasm structure, nuclei, mitochondrial and extracellular matrix in addition to other training protocols with variations in intensity and period of execution, would complement this work.

\section{CONCLUSION}

We concluded that after 14 weeks of training there was an increase in TAS when comparing the trained group with the untrained. Furthermore, it was possible to verify the hypertrophic effects in the slow and fast fibers.

CASTOLDI, R. C.; TEIXEIRA, G. R.; MALHEIRO, O. C. M.; CAMARGO, R. C. T.; BELANGERO, W. D. \& CAMARGO FILHO, J. C.S. Efecto de 14 semanas de entrenamiento de resistencia en el tejido muscular de ratas Wistar. Int. J. Morphol., 33(2):446$451,2015$.

RESUMEN: El objetivo fue investigar los efectos de 14 semanas de entrenamiento de resistencia sobre el tejido muscular de ratas Wistar. Fueron utilizadas 20 ratas, 10 en el grupo sin entrenamiento (Grupo 1) y 10 con entrenamiento (Grupo 2). El programa de entrenamiento físico estaba compuesto de cuatro series con 10 saltos acuáticos, tres veces en la semana, durante 14 semanas. Un aumento progresivo de la carga fue aplicado desde el día 14 al día 42. Los animales fueron eutanasiados con clorhidrato de potasio (100 mg/kg) intraperitoneal. La parte ventral del músculo gastrocnemio fue removida para el análisis histológico. La musculatura fue congelada en nitrógeno líquido y cortada con $5 \mu \mathrm{m}$ de espesor con micrótomo rotatorio. La coloración fue H-E para el análisis del músculo y área en las fibras musculares. La reacción com NADH-TR fue utilizada para la comparación entre las fibras rápidas (FR) y fibras lentas (FL). Las reacciones histoquímicass se observaron bajo microscópio de luz (Zeiss®) y sobre las microfotografias obtenidas se realizaron las mediciones con el programa Axio Vision (Zeiss®). El análisis estadístico se realizó con la prueba t de student para comparación de medias. Se observó una media de 5061,29 $\mu \mathrm{m}^{2}$ en el Grupo 1 y $5768,93 \mu \mathrm{m}^{2}$ en Grupo 2. Es posible concluir que 14 semanas de programa de entrenamiento físico con 10 saltos acuáticos son capaces de aumentar el área del músculo. Un aumento del área transversal de las FR y FL fue observado en el grupo 2.

PALABRAS CLAVE: Natación; Musculo estriado; Ejercicio físico.

\section{REFERENCIAS BIBLIOGRÁFICAS}

Armstrong, R. B. Mechanisms of exercise-induced delayed onset muscular soreness: a brief review. Med. Sci. Sports Exerc., 16(6):529-38, 1984.

Carmo, E. C.; Bueno Junior, C. R.; Fernandes, T.; Barretti, D.; Soares, S. F.; da Silva Junior, Na. D.; Uchida, M. C.; Brum, P. C. \& de Oliveira, E. M. O papel do esteroide anabolizante sobre a hipertrofia e força muscular em treinamentos de resistência aeróbia e de força. Rev. Bras. Med. Esporte, 17(3):212-7, 2011.

Carmo, E. M.; Rosim, F. E.; Soares, K. M. \& Lopes, F. S. Efeito do treinamento físico com diferentes temperaturas nas características morfológicas do músculo sóleo de ratos. Arq. Ciênc. Saúde Unipar, 12(2):85-92, 2008.
Castoldi, R. C.; Camargo, R. C. T.; Magalhães, A. J. B.; Ozaki, G. A. T.; Kodama, F. Y.; Oikawa, S. M.; Papoti, M. \& Camargo Filho, J. C. S. Concurrent training effect on muscle fibers in Wistar rats. Motr. Rev. Educ. Fis., 19(4):717-23, 2013.

Castoldi, R. C.; Moret, D. G.; Gomes, I. C.; Paulo, T. R. S.; Oikawa, S. M. \& Freitas Júnior, I. F. Influência da adiposidade corporal sobre a aptidão cardiorrespiratória em mulheres idosas. Rev. Bras. Cienc. Mov., 18(4):348, 2010.

Cooper, C. B. Exercise in chronic pulmonary disease: limitations and rehabilitation. Med. Sci. Sports Exerc., 33(7 Suppl.):S643-6, 2001. 
Deforges, S.; Branchu, J.; Biondi, O.; Grondard, C.; Pariset, C.; Lécolle, S.; Lopes, P.; Vidal, P. P.; Chanoine, C. \& Charbonnier, F. Motoneuron survival is promoted by specific exercise in a mouse model of amyotrophic lateral sclerosis. J. Physiol., 587(Pt. 14):3561-72, 2009.

Ferolla, F.; Castoldi, R. C.; Fernández, R. A.; de Mello Malheiro, O. C.; Oikawa, S. M. \& Freitas Júnior, I. F. Nível educacional e prática de atividade física em áreas publicas do município de Presidente Prudente. Rev. Digit., 14(142), 2010. Disponible en: http:// www.efdeportes.com/efd142/nivel-educacional-epratica-de-atividade-fisica.htm

Fleck, S. \& Kraemer, W. J. Fundamentos do Treinamento de Força Muscular. 3a ed. Porto Alegre, ArtmedBookman, 2006.

Freitas Júnior, I. F.; Castoldi, R. C.; Moreti, D. G.; Pereira, M. L.; Cardoso, M. L.; Codogno, J. S.; Fernandes, R. A.; Bueno, D. R. \& Gomes, J. O. Aptidão física, história familiar e ocorrência de hipertensão arterial, osteoporose, doenças metabólicas e cardíacas entre mulheres. Rev. $S$. O. C. E. R. J., 22(3):158-64, 2009.

Kottke, T. E.; Faith, D. A.; Jordan, C. O.; Pronk, N. P.; Thomas, R. J. \& Capewell, S. The comparative effectiveness of heart disease prevention and treatment strategies. Am. J. Prev. Med., 36(1):82-8, 2009.

Lanza, I. R. \& Nair, K. S. Mitochondrial function as a determinant of life span. Pflugers Arch., 459(2):277-89, 2010.

Lüdorf, S. M. A. Corpo e formação de professores de educação física. Interface Comun. Saúde Educ., 13(28):99-110, 2009.

Machado, A. G. \& Ribeiro, P. C. P. Anabolizantes e seus riscos. Adolesc. Saúde, 1(4):20-2, 2004.

Meloni, V. H. M. O papel da hiperplasia na hipertrofia do músculo esqulético. Rev. Bras. Cineantropom. Desempenho Hum., 7(1):59-63, 2005.

Pinto, V. S.; de Sousa, V. P. \& Cameron, L. C. As bases estruturais e moleculares da contração muscular. Fisioter. Bras., 5(4):298-306, 2004.

Sigoli, M. A. \& De Rose Jr., D. The history of sport's political use. Rev. Bras. Cienc. Movim., 12(2):111-9, 2004.

Spagnol, A. R.; Malheiro, O. C. M.; Castoldi, R. C.; Moret,
D. G.; Araújo, R. G.; Papoti, M.; Camargo, R. C. T. \& Camargo Filho, J. C. S. Análise da plasticidade muscular de ratos submetidos a um protocolo de treinamento físico concorrente. Rev. Bras. Cienc. Movim., 20(3):11824, 2012.

Taaffe, D. R.; Henwood, T. R.; Nalls, M. A.; Walker, D. G.; Lang, T. F. \& Harris, T. B. Alterations in muscle attenuation following detraining and retraining in resistance-trained older adults. Gerontology, 55(2):21723, 2009.

Teixeira, L. S.; Martins, L.; de Godói, S. C. \& Casa Júnior, A. J. Corrente excitomotora e força muscular em reabilitação: revisão de literatura. Rev. Digit., 13(121), 2008. Disponible en: http://www.efdeportes.com/efd121/ corrente-excitomotora-e-forca-muscular-emreabilitacao.htm

Zorzetto, N. L. Curso de Anatomia Humana. $3^{\text {a }}$ ed. São Paulo, IBEP, 1979. p.75.

Correspondence to:

Profa. Dra. Giovana Rampazzo Teixeira

Departamento de Educação Física

UNESP/FCT - Campus de Presidente Prudente

Rua Roberto Simonsen, 305

Bairro: Centro Educacional

CEP:19060-900 - Pres. Prudente, SP

BRAZIL

Telephone: 55 (18) 32295829

Email: giovana@fct.unesp.br

Received: 19-05-2014

Accepted: 24-02-2015 